\title{
Milk yield and composition in dairy goats fed different levels of extruded soyabeans*
}

\author{
A. Doyon, C. Ridorossi and P.Y. Chouinard ${ }^{1}$ \\ ${ }^{1}$ Département des Sciences Animales, Université Laval \\ Québec, Canada G1K 7P4
}

\begin{abstract}
Sixteen dairy goats were assigned to a $4 \times 4$ Latin square design. Full-fat extruded soyabeans (EXSB) were fed at rates of $0,150,300$, and $400 \mathrm{~g} / \mathrm{day}$, and grass hay was fed for ad libitum intake. Dietary EXSB had no effect on milk yield and milk fat content $(\mathrm{P}>0.05)$. Feeding increasing levels of EXSB linearly increased the concentrations of casein and whey protein in milk, and the concentration of conjugated linoleic acids in milk fat $(\mathrm{P}<0.05)$. Feeding EXSB has the potential to improve the quality of milk for processing as well as the nutritive value of milk fat.
\end{abstract}

KEY WORDS: extruded soyabeans, dairy goats, milk protein fractions, conjugated linoleic acids

\section{INTRODUCTION}

Full-fat soyabeans are of interest as a source of protein and energy in the ration of high yielding dairy ruminants. Various heat treatments have been applied to increase proportions of undegradable protein in the rumen when full-fat soyabeans are fed to lactating cows. Attention has also been given to the influence of heattreated full-fat soyabeans on the fatty acid composition of milk fat. In the diets of dairy cows, extruded soyabeans (EXSB), but not ground raw soyabeans, elevated the proportions of conjugated linoleic acids (CLA) in milk fat (Chouinard et al., 2001). Conjugated linoleic acids are components of ruminant fat that are of interest since biomedical studies with animal models have demonstrated a number of beneficial health effects. Feeding EXSB would therefore improve the nutritive value of milk fat from a human health point of view. However, similar feeding strategies have not been extensively evaluated with dairy goats. Our objective was

\footnotetext{
* Supported by the Conseil des Recherches en Pêche et en Agro-alimentaire du Québec and the Conseil pour le Développement de L'Agriculture du Québec

${ }^{1}$ Corresponding author: e-mail: Yvan.Chouinard@san.ulaval.ca
} 
to examine the effects of diets containing increasing levels of EXSB on milk yield, milk composition and milk fatty acid profile in dairy goats.

\section{MATERIAL AND METHODS}

Sixteen primiparous dairy goats that averaged 120 days in milk were randomly assigned to a $4 \times 4$ Latin square design with 21 -day periods. Two squares were composed of Saanen goats, one square was composed of Toggenbourg goats, and one square was composed of Alpine goats. Full-fat EXSB were fed at rates of 0 , 150,300 , and $400 \mathrm{~g} /$ day as part of grain mixes formulated to be isonitrogenous (Table 1). Chopped grass hay was fed ad libitum.

The first two weeks of each period were used for adjustment to diets and week 3 was used for data collection. During each of these periods, goat weight was recorded for three consecutive days. Hay intake was determined and feed ingredients were sampled for four consecutive days. Milk yield was recorded for six consecutive milkings, and milk was sampled proportionately to milk yield.

Table 1. Ingredient composition of the experimental grain mixes

\begin{tabular}{lcccc}
\hline \multirow{2}{*}{ Ingredient, \% of DM } & \multicolumn{4}{c}{ Extruded soyabeans, g/d } \\
\cline { 2 - 5 } & 70.4 & 150 & 300 & 450 \\
\hline Cracked maize & 23.1 & 15.4 & 63.5 & 60.3 \\
Soyabean meal & - & 11.2 & 7.8 & - \\
Extruded soyabean & 1.8 & 1.8 & 1.8 & 33.3 \\
Molasses & 4.0 & 4.0 & 4.0 & 1.8 \\
Vitamin and mineral premix & 0.7 & 0.7 & 0.7 & 4.0 \\
Vitamin E (50 000 IU/kg) & & & & 0.7 \\
\hline
\end{tabular}

\section{RESULTS}

Mean body weight and body weight change were unaffected by treatments. Forage intake expressed as kilograms per day or as a percentage of body weight was not different among treatments. Milk yield and milk corrected for fat and protein content were also unaffected by the level of EXSB supplemented in the diet (Table 2).

The percentage and yield of milk fat did not differ among treatments. Milk crude protein percentage increased linearly with the level of EXSB in the diet. However, milk protein yield was similar among treatments. The percentages of true protein, casein, whey protein, and non casein nitrogen in milk increased linearly with the level of dietary EXSB (Table 3 ). The concentration of non protein nitrogen was unaffected by treatments. As a result, true protein expressed as a proportion of crude protein increased linearly with the level of EXSB in the diet. Casein expressed as a proportion of true protein was not affected by treatments. 
However, the ratio of casein to whey protein decreased linearly with the level of dietary soyabeans.

Feeding increasing amounts of EXSB linearly decreased the proportion of short- and medium-chain fatty acids in milk fat (Table 4). The proportions of $\mathrm{C} 18$ fatty acids increased linearly with the level of dietary EXSB.

Table 2. Body weight, dry matter intake, and milk yield of goats fed extruded soyabeans

\begin{tabular}{|c|c|c|c|c|c|c|c|c|}
\hline \multirow{2}{*}{ Item } & \multicolumn{4}{|c|}{ Extruded soyabeans, g/d } & \multirow{2}{*}{ SEM } & \multicolumn{3}{|c|}{ Contrast } \\
\hline & 0 & 150 & 300 & 450 & & $\mathrm{~L}$ & Q & $\mathrm{C}$ \\
\hline \multicolumn{9}{|l|}{ Body weight } \\
\hline actual, $\mathrm{kg}$ & 49.6 & 49.6 & 49.9 & 49.5 & 0.27 & 0.85 & 0.46 & 0.56 \\
\hline change, $\mathrm{kg} / \mathrm{d}$ & 0.03 & 0.02 & 0.03 & 0.04 & 0.01 & 0.34 & 0.41 & 0.64 \\
\hline \multicolumn{9}{|l|}{ Forage intake } \\
\hline $\mathrm{kg}$ dry matter/d & 0.93 & 0.96 & 0.93 & 0.90 & 0.03 & 0.41 & 0.39 & 0.77 \\
\hline$\%$ of body weight & 1.88 & 1.93 & 1.88 & 1.81 & 0.07 & 0.36 & 0.36 & 0.79 \\
\hline \multicolumn{9}{|l|}{ Milk yield } \\
\hline actual, $\mathrm{kg} / \mathrm{d}$ & 2.51 & 2.51 & 2.56 & 2.46 & 0.06 & 0.73 & 0.44 & 0.46 \\
\hline corrected $^{1}, \mathrm{~kg} / \mathrm{d}$ & 2.27 & 2.28 & 2.35 & 2.29 & 0.06 & 0.71 & 0.55 & 0.53 \\
\hline
\end{tabular}

${ }^{1}$ corrected milk yield $=$ milk $(\mathrm{kg}) \times[203.8+[83.6 \times$ fat $(\%)]+[62.9 \times$ protein $(\%)] / 666]$

Table 3. Concentration and yield of milk constituents for goats fed extruded soyabeans

\begin{tabular}{lccccccccc}
\hline \multirow{2}{*}{ Item } & \multicolumn{4}{c}{ Extruded soyabeans, g/d } & \multirow{4}{c}{ Contrast } \\
\cline { 2 - 5 } \cline { 7 - 8 } & \multicolumn{2}{c}{0} & \multicolumn{1}{c}{150} & 300 & 450 & & $\mathrm{~L}$ & $\mathrm{Q}$ & $\mathrm{C}$ \\
\hline Fat, \% & 2.39 & 2.44 & 2.43 & 2.47 & 0.04 & 0.19 & 0.94 & 0.48 \\
Fat, g/d & 60 & 61 & 62 & 61 & 2 & 0.73 & 0.60 & 0.74 \\
Crude protein, (CP) \% & 3.13 & 3.14 & 3.23 & 3.31 & 0.04 & $<0.01$ & 0.33 & 0.65 \\
Crude protein, g/d & 79 & 79 & 83 & 82 & 2 & 0.28 & 0.33 & 0.65 \\
True protein (TP), \% & 2.88 & 2.89 & 2.97 & 3.06 & 0.04 & $<0.01$ & 0.29 & 0.63 \\
Casein, \% & 2.37 & 2.39 & 2.44 & 2.50 & 0.04 & $<0.01$ & 0.04 & 0.42 \\
Whey protein, \% & 0.51 & 0.50 & 0.53 & 0.56 & $0.01<0.01$ & 0.04 & 0.42 \\
Non protein N, \% & 0.04 & 0.04 & 0.04 & 0.039 & 0.001 & 0.33 & 0.21 & 0.88 \\
Non casein N, \% & 0.119 & 0.118 & 0.123 & 0.128 & $0.002<0.01$ & 0.07 & 0.41 \\
Casein, \% of TP & 82.4 & 82.8 & 82.2 & 81.6 & 0.35 & 0.06 & 0.16 & 0.58 \\
True protein, \% of CP & 91.8 & 91.8 & 92.1 & 92.4 & 0.17 & $<0.01$ & 0.28 & 0.81 \\
Casein:whey protein & 4.8 & 4.9 & 4.8 & 4.5 & 0.10 & 0.04 & 0.15 & 0.83 \\
\hline
\end{tabular}

\section{DISCUSSION}

The current experiment shows that feeding EXSB had no major effect on production performances of lactating dairy goats. However, dietary EXSB increased the concentration of casein and whey protein in milk without affecting the proportion of non protein nitrogen. Increasing milk casein content is known to improve cheese yield. 
Table 4. Fatty acid profile of milk fat from goats fed extruded soyabeans

\begin{tabular}{|c|c|c|c|c|c|c|c|c|}
\hline \multirow{2}{*}{ Item } & \multicolumn{4}{|c|}{ Extruded soyabeans, g/d } & \multirow{2}{*}{ SEM } & \multicolumn{3}{|c|}{ Contrast } \\
\hline & 0 & 150 & 300 & 450 & & $\mathrm{~L}$ & $\mathrm{Q}$ & $\mathrm{C}$ \\
\hline $\mathrm{C} 4: 0$ & 5.40 & 5.52 & 5.44 & 5.35 & 0.04 & 0.52 & 0.17 & 0.25 \\
\hline C6:0 & 3.40 & 3.40 & 3.21 & 3.07 & 0.05 & $<0.01$ & 0.18 & 0.25 \\
\hline C8:0 & 3.23 & 3.17 & 2.90 & 2.72 & 0.05 & $<0.01$ & 0.27 & 0.21 \\
\hline C10:0 & 9.60 & 8.81 & 7.81 & 7.06 & 0.16 & $<0.01$ & 0.89 & 0.54 \\
\hline C12:0 & 4.05 & 3.47 & 3.08 & 2.76 & 0.07 & $<0.01$ & 0.07 & 0.71 \\
\hline C14:0 & 9.75 & 8.42 & 7.59 & 6.70 & 0.17 & $<0.01$ & 0.20 & 0.45 \\
\hline C14:1 & 0.11 & 0.08 & 0.07 & 0.06 & 0.004 & $<0.01$ & 0.12 & 0.52 \\
\hline C15:0 & 0.77 & 0.66 & 0.66 & 0.65 & 0.02 & $<0.01$ & 0.02 & 0.18 \\
\hline C16:0 & 24.0 & 21.2 & 19.5 & 18.4 & 0.24 & $<0.01$ & $<0.01$ & 0.69 \\
\hline C16:1 & 0.30 & 0.27 & 0.24 & 0.23 & 0.01 & $<0.01$ & 0.71 & 0.67 \\
\hline C17:0 & 0.45 & 0.44 & 0.41 & 0.38 & 0.02 & $<0.01$ & 0.52 & 0.73 \\
\hline C18:0 & 12.1 & 14.3 & 16.4 & 17.6 & 0.03 & $<0.01$ & 0.05 & 0.40 \\
\hline trans $\mathrm{C} 18: 1$ & 2.11 & 2.80 & 3.83 & 4.58 & 0.15 & $<0.01$ & 0.84 & 0.34 \\
\hline cis $\mathrm{C} 18: 1$ & 21.9 & 24.1 & 25.0 & 25.8 & 0.54 & $<0.01$ & 0.18 & 0.58 \\
\hline C18:2 & 2.08 & 2.39 & 2.60 & 3.18 & 0.06 & $<0.01$ & 0.05 & 0.13 \\
\hline C18:3 & 0.31 & 0.34 & 0.36 & 0.42 & 0.01 & $<0.01$ & 0.11 & 0.16 \\
\hline $\begin{array}{l}\text { Conjugated } \\
\text { C18:2 }\end{array}$ & 0.48 & 0.59 & 0.87 & 1.07 & 0.05 & $<0.01$ & 0.38 & 0.25 \\
\hline
\end{tabular}

One of the objectives of this study was also to examine the effects of dietary full-fat soyabeans on the fatty acid profile of milk fat including CLA concentrations. The CLA content increased by $123 \%$ in milk fat of goats fed EXSB at the rate of $450 \mathrm{~g} / \mathrm{d}$ as compared with unsupplemented diet. Previous investigations (Chouinard et al., 2001) involving dietary addition of processed soyabeans in dairy cows have shown increases in milk fat concentration of CLA similar to those observed in the current study with dairy goats.

\section{CONCLUSIONS}

Feeding EXSB has the potential to improve the quality of milk for processing as well as the nutritive value of milk fat without affecting production performance in dairy goats.

\section{REFERENCES}

Chouinard P.Y., Corneau L., Butler W.R., Chilliard Y., Drackley J.K., Bauman D.E., 2001. Effect of dietary lipid source on conjugated linoleic acid concentrations in milk fat. J. Dairy Sci. 84, $680-690$ 